\title{
Chapter 13. Sea Nomads and Rainforest Hunter-Gatherers: Foraging Adaptations in the Indo-Malaysian Archipelago
}

\section{Clifford Sather}

This chapter discusses the non-agricultural aspects of Austronesian history and ethnography, taking the basic view that the early Austronesian colonizations might have involved a range of both food producing and foraging economies and that sharp dichotomies between the two kinds of economy are unlikely to have existed. Modern Austronesian hunter-gatherers such as the Agta and Penan cannot be seen as "fossilized" foragers from the Pleistocene, but, like the Semang, as parties to a process of symbiosis with agriculturalists which has continued for several millennia. The idea of "devolution" from a prior dependence on agriculture amongst the Penan is critically assessed and rejected. Also discussed are the historical roles of the Sea Nomads - Moken, Orang Laut and Sama-Bajau.

\section{Introduction}

Peter Bellwood (1985:205) has proposed that the first "Austronesian-speakers who expanded into the Indo-Malaysian Archipelago carried [with them] a fully agricultural economy". If this is so - and the evidence in support of the proposition is compelling - then the status of contemporary foraging groups in Island Southeast Asia, whose members speak Austronesian languages, must be seen as problematic. Clearly such groups cannot be said to have preserved in any simple or direct sense a form of adaptation ancestral to Austronesian colonization. How, then, are we to place these non-agricultural societies in the history of the Austronesian-speaking world? It is this question that I want to consider here, looking, in particular, at maritime boat nomads, groups whose mode of adaptation appears to be unique to the Indo-Malaysian Archipelago, and to rainforest hunter-gatherers, particularly those of central and western Borneo.

Much of the answer to the question I pose here hinges, I shall argue, on the role of exchange and concomitant economic diversity in the early history of Austronesian adaptation. Although others have also stressed the significance of exchange (e.g. Dunn 1975; Hutterer 1976, 1977; Peterson 1978; Urry 1981), I approach the question here, not as a prehistorian, but from the vantage point of historical ethnography, extrapolating, as it were, from the "ethnographic present" back into the past. While I have tried to draw supporting evidence, 
where available, from archaeology, linguistics, biology and history, much of this extrapolation is clearly conjectural.

\section{Problems in the Ethnogenesis of Southeast Asian Hunter-Gatherers}

In recent years it has come to be acknowledged that contemporary hunter-gatherers, rather than representing forms of organization that evolved during the Palaeolithic and persisted unchanged ever since, are the products of continuing evolutionary processes and, in some cases, of interaction with other populations, including agriculturalists and even, in recent times, centralized states (cf. Schrire 1984). Thus, while not denying the great antiquity of hunting and gathering, most scholars today would agree with Lewin (1988:1147) that,

... modern hunter-gathering is a largely post-Pleistocene phenomenon. Rather than being an adaptation ancestral to food production, it is [in effect] a parallel development.

Following from this, Headland and Reid (1989:43) apply what they call an "interdependent model" of foraging to reinterpret the situation of one group of Island Southeast Asian hunter-gatherers - the Philippine Negritos. The Negritos are of special interest because, unlike other Austronesian-speaking foragers, they appear to be biologically distinct from the Austronesian-speaking cultivators who live surrounding them. Their ancestors are therefore believed to have been present in the Philippines, and possibly elsewhere in Island Southeast Asia, prior to the arrival of the first Austronesian agriculturalists (Headland and Reid 1989: 46; see also Bellwood 1985:113). On the basis of linguistic evidence, Headland and Reid (1989:46) propose that:

At some time in the prehistoric past, the ancestors of today's Negritos must have established ... contact with the Austronesian-speaking immigrants in the course of which they lost their own languages and adopted those of the newcomers. In order for a language switch of this magnitude to have occurred, [this contact must have been both intense and of long duration. Moreover, ...t]he linguistic data suggests that all this happened a very long time ago ... well over a thousand years in the case of the Negrito languages that are today most similar to their non-Negrito sister languages and of many thousands of years in the case of those that are least similar.

The evidence thus points to a protracted interaction between Negrito foragers and Austronesian cultivators that must have begun virtually at once, as soon as the first Austronesians arrived in northern Luzon, perhaps 4500 to 5000 years ago (cf. Bellwood 1985:120; Reid 1987). Thus, rather than representing a "static 
window on the Paleolithic past", Negrito society must be seen as an adaptive product of prolonged contact.

From the linguistic evidence, Headland and Reid (1989:47) go on to argue that:

The interdependence of Negritos and farming populations observable today has existed much longer than most scholars have thought. [While t]here is no question that the ancestors of the present-day [Negritos] were at one time Paleolithic hunter-gatherers, [the point to be made] is that this Stone Age lifestyle ended long ago, probably by the middle Holocene, and that prehistoric Negritos probably moved into the Neolithic at more or less the same time as their neighbors.

Here Headland and Reid add another element to their argument. This is a notion that the Negritos first moved into the ever-wet rainforests, the habitat with which the majority are now identified, only after they had acquired at least seasonal access to cultivated foods (see also Headland 1987; Peterson 1978; Peterson and Peterson 1977). Until then, Headland (1987) maintains, they probably occupied only the margins of the rainforest, the coastal zone and more open areas of monsoon forest and parklands. Following from this, Headland and Reid (1989:47) propose,

that the symbiotic relationship we find today between tropical forest hunter-gatherers and farmers evolved long ago as an adaptive strategy for exploiting the tropical forest.

This argument they link to one concerning the ethnogenesis of Southeast Asian Negrito cultures generally: namely (1989:47),

that the Negritos evolved culturally into what they are today as they moved into the forest to collect wild products to trade with agriculturalists and overseas traders.

Negrito cultures are thus an innovative product of contact and economic interaction. In this case, contact between pre-existing foragers and Austronesian farmers resulted, not only in the former borrowing the languages of the latter, but in the two becoming mutually enveloped in a symbiotic economy. One consequence of this envelopment was a kind of radial adaptation that allowed the foraging partners in the system to invade and successfully exploit what may have been, until then, a relatively unutilized habitat - the ever-wet rainforest. I will return later to consider a more general form of this argument.

First, however, it must be noted that Headland's thesis rests upon a view of the ever-wet rainforest as an inhospitable habitat incapable of supporting populations of independent foragers (1987; also Bailey et al. 1989). This view is by no means securely established and recently Bellwood (1993), using 
archaeological evidence, and Endicott and Bellwood (1991), using both ethnographic and archaeological data, have made a convincing case that self-sufficient foraging is not only possible but has historically been present, both in the prehistoric past and more recently among contemporary Batek Negrito communities living today in the ever-wet rainforests of the Malay Peninsula (see also Endicott 1984). More generally, Endicott and Bellwood (1991) conclude that, while "tropical rain forests vary in their potential for supporting human foraging", in some areas at least, "small nomadic groups of foragers can live off wild resources alone" and, indeed, have done so in the past, although "the paucity of resources" tends to make such groups opportunistic, and "one of the opportunities they are quick to take up is the opportunity to trade for agricultural produce".

Whether foragers occupied the tropical rainforests before Austronesian colonization or not, Bellwood (1985:132) argues that, in either case, if Austronesian-speakers initially arrived in the Indo-Malaysian Archipelago as cultivators, then, logically, "hunting and collecting societies", whose members now speak Austronesian languages, can have originated in one of two possible ways. They may

have either survived assimilation by, or have adapted out of [an] expanding Austronesian agricultural economy (1985:132).

In other words, they may, like the Philippine Negritos, derive from an earlier population whose members "resisted acculturation by surrounding cultivators", or they may have taken up foraging later on, after their entry into the Indo-Malaysian Archipelago, "as a result of change from an agricultural ancestry" (Bellwood 1985:132).

Except for the Philippine Negritos, all other Austronesian-speaking hunter-gatherers in Island Southeast Asia appear to be genetically indistinguishable from the agricultural populations present around them. In order to account for their presence it has been suggested for Borneo that such foragers are "devolved agriculturalists" (Blust 1989; Hoffman 1984, 1986), the descendants of Austronesian cultivators who moved into the rainforest in order to engage in the collection of forest products for trade. While this argument has gained some acceptance outside of Borneo (cf. Bailey et al. 1989), the ethnographic evidence supporting it has not been well marshalled, and anthropologists working with contemporary hunter-gatherers in Sarawak and Kalimantan are considerably more critical (cf. Brosius 1988, 1991; Sellato 1988). At the end of the paper I will examine some of the reasons why this is so and look briefly at several alternative arguments. Together, these point up, as we shall see, a rather more complex solution. 
First, however, it is useful to consider briefly the adaptive history of the Aboriginal (Aslian) peoples of the Malay Peninsula. Although most are Austroasiatic- rather than Austronesian-speaking, the history of these groups presents us with a valuable comparison; it also interpenetrates, in more recent times, with the story of Austronesian expansion.

Benjamin, in a series of valuable papers $(1979,1985,1986)$, has proposed a model for the development of the three major Aboriginal groupings of the Malay Peninsula: 1) nomadic foragers in the north (the "Semang"); 2) sedentary swidden farmers in the central uplands (the "Senoi"); and 3) southern lowland forest collectors-for-trade (the "Aboriginal Malay"). ${ }^{1}$ His underlying argument is that (1986:5),

the present-day array of indigenous cultures in the Peninsula [has] come about through processes of mutual dissimilation or assimilation (as the case may be) within an essentially common cultural frame.

In other words, each of these major traditions arose, Benjamin (1986:10) argues, out of a common cultural matrix, and in assuming its distinctive form, was shaped, not only by ecological forces, but also by socio-cultural choices made by its members in full awareness of the "ways of doing things" practised by the members of each of the other traditions. Each tradition thus emerged, not out of isolation or from lack of contact, but as a result of "differentiated responses to a heightened attachment to foraging, swiddening, and collection-for-trade", made by groups whose members saw "themselves, complementarily, as part of each other's environment" (Benjamin 1986:10).

Benjamin suggests that food crops began to be cultivated in the Malay Peninsula by about 5000 years ago and so made sedentism a possible option. Among these crops were both cereals and root-crops (cf. Dunn 1975; Peacock 1979). Initially, however, while allowing for a broader spectrum of subsistence modes, the Peninsula was not, Benjamin (1986:12) maintains, well-adapted to sedentary farming. Instead, its economic hallmark was diversity. Not only was there variation in crops and patterns of cultivation but also in subsistence modes themselves, which besides farming, included forest hunting-gathering, strand-foraging, fishing and trade (see also Dunn 1975). While this diversity allowed for considerable adaptive flexibility, it did not lead, initially at least, to a rapid run up of population or to the development of higher levels of socio-cultural integration. Both came only much later. Initially, Benjamin (1986:14) asserts, the social and demographic patterns of farming communities were not very different from those that continued to subsist by foraging. Indeed, he suggests that most groups probably combined both foraging and farming, much as do upland "Senoi" groups today (Benjamin 1986:13). Thus, while foragers planted crops from time to time, farmers continued to engage in hunting and gathering. In Benjamin's view, until some 2000 years ago, the Aboriginal 
cultures of the Peninsula, while internally diverse, remained socially and economically undifferentiated.

Here a cautionary note is in order. Almost certainly Benjamin overstates the in situ nature of these developments (cf. Bellwood 1993). Recent archaeological evidence points to a marked discontinuity between foraging "Hoabinhian" communities and subsequent Neolithic assemblages, indicating that cultivation, and in particular the introduction of rice-agriculture, brought about significant demographic and social organizational changes (Bellwood 1993). Moreover, agriculture appears to have entered the Peninsula from the north and was probably carried southward by Austroasiatic-speakers, including among them, very likely, the ancestors of the present-day "Senoi". Like the Philippine Negritos, the ancestors of the Semang appear to have similarly undergone an early language "switch" as a consequence of this southward expansion of agriculturalists, thus becoming Austroasiatic-speaking like their neighbours. As Bellwood (1993) notes, this tandem spread of language and agriculture appears to parallel the spread of Austronesian-speaking agriculturalists to the east. Both seemingly represent a continuous expansion of a rice cultivating population to the south, commencing about $3000 \mathrm{BC}$, with, in this instance, its ultimate products impacting on the Malay Peninsula from two opposed directions, the Austroasiatics from the north, the Austronesians from the south.

These qualifications aside, the fact that the ancestors of the Semang underwent a language "switch", and that the Austroasiatic languages now spoken in the Malay Peninsula are as highly differentiated as they are, all point, as Benjamin rightly argues, to an impressive history of local contact and development.

Later, in the south, contact with Austronesian mariners began a process of internal differentiation. Thus,

the Peninsular coastline began to be contacted by "oceanic nomads", making available the further option of trading in forest products with outsiders ... At first these Austronesian-speaking mariners would have seemed exotic to the Austroasiatic-speaking land-dwellers, but it would not have been very long before certain parts of the Peninsula (the coastal lowlands and the south in particular) would, by cultural assimilation and intermarriage, have become an extension inland of the Austronesian world (Benjamin 1986:11).

In the northern and central regions of the Peninsula, around the same time, farming became efficient enough to allow for the emergence of a more overtly differentiated array of cultures (1986:14). Thus Benjamin suggests that while swiddeners were able to intensify their sedentism as a result, foragers, the ancestors of the present-day "Semang", became, in response, even "more nomadic..., cutting down ... further their sedentary periods of desultory 
swidden-tending" (1986:14). Thus, while both sedentism and rainforest foraging had long been options, the marked differentiation of the two came about only much later, through a process of "mutual socio-cultural dissimilation" (Benjamin 1986:15).

In this process of dissimilation, different patterns of social organization were generated as each group came to emphasize what Benjamin (1986:6) calls "deliberately-constructed carriers of ecologically-related meanings and values". One example he discusses are rules of marriageability. Thus, among the foraging Semang, cross-sex avoidances, especially between siblings- and cousins-in-law, produced, Benjamin argues, "a mental image of anti-sedentism" by picturing the ideal society as one constituted of easily detachable conjugal-family groups, linked together by marriages contractible only between those who are not previously related either by consanguinity or affinity. This image, coupled with low population density, compels a "readiness to wander far and wide in search, not only of food, but of social relations" (1986:14). The result is a social organization that is both well-suited to nomadic survival, but also, through its scheme of values, one which irreversibly commits those who practise it to a nomadic mode of life. In contrast, the agricultural Senoi "switched signs" and imposed joking relations where the Semang imposed avoidance, thereby making it, not proscribed, but desirable to marry someone from the same group into which one's siblings and cousins had already married. In this way intermarrying kin groups were consolidated and a premium was placed on sedentism rather than mobility. This difference "not only proclaimed that Senoi ways were different from Semang ways", but provided a further reason for rejecting the other. In consequence,

two quite complementary patterns of social praxis were evolved and locked into place (Benjamin 1986:15).

Finally, by the end of the first millennium AD, among the now Austronesian-speaking peoples of the southern lowlands (and in the neighbouring coastal regions of Borneo and Sumatra), petty chiefdoms became progressively "nested" within one another to form small-scale states (cf. Benjamin 1985; Wolters 1967, 1979). This process of state formation almost certainly involved boat-dwelling mariners - the peoples whose adaptation I turn to presently who acted as "integrating information-carriers" linking together, as agents in this process, the emerging courts, subsidiary chiefs and a developing peasantry (Benjamin 1986:16).

\section{Adaptive Diversity in Early Austronesian Society}

In order to bring together our discussion so far, it is useful to return to the notion, introduced at the beginning of the paper, of communities enmeshed in systems of symbiotic interaction, at once interconnected but economically diverse. 
Here I want to suggest that such a pattern was probably an integral feature of early Austronesian society.

Current linguistic evidence places the beginning of Austronesian expansion, initially involving most likely groups from Taiwan moving southward into the northern Philippines, at around 5000 BP (Bellwood 1985:107-121; Pawley and Green 1973:52-54). Bellwood (1985) has proposed a comprehensive model of this expansion based primarily on linguistic and archaeological evidence. According to this model, carriers of Austronesian languages essentially moved southward, settling the islands they encountered with an economy based on agriculture, focused initially on cereals, rice in particular, but adding as they moved southward a variety of tuber and tree crops which in some areas replaced rice as the locally dominant staples.

Without disputing this model, it should not be taken to imply that all early Austronesians were equally committed to rice agriculture. This seems unlikely. Instead, they probably included groups practising a comparatively broad spectrum of economic activities, including trade and, in addition to farming, elements of secondary foraging, hunting, fishing and marine collection (cf. Pawley and Green 1973:35-36). This is not to suggest that the early Austronesians subsisted as full-time foragers, and certainly not as rainforest hunters and gatherers. Rather, what appears to have distinguished the early Austronesians was, almost certainly, the existence of a strong maritime element and, as a concomitant of economic diversity, the presence of significant relations of exchange. Although not full-time foragers themselves, the early Austronesians almost certainly initiated, by their arrival in Island Southeast Asia, two major innovations, both of them associated with exchange, that transformed the nature of foraging in the region: namely - (1) the creation of a special niche for forest collectors-for-trade and (2) the envelopment of foraging groups with agriculturalists and others in a diversified economy.

The principal evidence that the proto-Austronesians practised rice agriculture comes from linguistic reconstructions, and most especially from the work of Robert Blust (1976). This evidence also points to economic diversity. Thus, the early Austronesians appear to have possessed a diverse technology which Blust (1976:37) describes as a "mixed picture" — "with stone tools next to iron, probably bark cloth next to textiles, root crops next to grains". While Blust (1984-5) has since revised his views somewhat, particularly in regard to iron, the picture he presents remains a complex one. Rice agriculture is certainly a major feature, but, at the same time, the evidence suggests,

a polymorphous economic base incompatible with the somewhat rigid notion of "progress" from one exclusive level to the next (Blust 1976:37). 
Economic polymorphism is also suggested by the archaeological record, incomplete as it is. Thus, Bellwood (1985:159), in discussing the gradual southward expansion of Austronesian-speakers, while stressing the propelling role of agriculture, points up the continuing presence of foraging adaptations, noting that (1985:159):

This expansion was not a geographically unified process of replacement. The hunting and gathering lifestyle has been progressively eroded but it has certainly never disappeared entirely ... Hence in recent millennia different technologies and economies could and did occur in neighbouring and contemporary sites in a mosaic-like fashion (Hutterer 1976).

Later I will suggest that, in addition to agriculture, the continuing presence of secondary foraging may, indeed, have contributed to the success of the early Austronesians as colonizers. At the same time, the envelopment of foragers in a more diversified economy may have increased the effectiveness of foraging itself, possibly drawing new groups into this niche.

Finally, while cereal cultivation appears to have been a major factor in Austronesian expansion, the Proto-Austronesians, it is equally clear, were not an exclusively land-oriented people. Thus, linguistic evidence confirms the existence of an early and well-developed maritime tradition (Blust 1976:36) and with it, very likely, a pattern of sea-going trade.

While economic diversity might not have contributed to population density, it seems likely to have encouraged a centrifugal, outward-movement of people, one consequence of which may well have been the incorporation of still greater diversity. As I will suggest later, secondary foraging probably played a role in this, facilitating both expansion and the incorporation of new crops and cultivation methods as expanding groups colonized new environments. Moreover, by holding open, initially at least, the option of a thorough-going sedentism, the early Austronesians succeeded as colonizers, pursuing a variety of adaptive strategies and adding new ones as they colonized new environments, while preserving, at the same time, the possibility of future socio-cultural complexity.

Finally, from the outset, the Austronesians must have been able, as a result of economic interaction and exchange, not only to envelop and so transform existing foragers, but also to develop and enmesh new lines of economic adaptation, including in time, new varieties of foraging particularly geared to the region's unique environments - to its ever-wet rainforests and, even more importantly, to its vast archipelagic seas.

\section{The Pre-Eminence of the Sea}

Urry (1981) has made a powerful argument that, because of its role in communications, the sea constitutes the dominant factor in the prehistory of the 
Indo-Malaysian region. Geographically the archipelago consists of thousands of islands, joined by relatively shallow, warm seas ideally situated for easy communication, while, in contrast, the larger islands of the region are often difficult to penetrate, except where river systems reach inland, forming, as it were, extensions of the sea (Urry 1981:2-3).

It is not known how long the sea may have exerted this pre-eminence. But Urry suggests that its importance began to be felt by at least the end of the Pleistocene, when ocean levels altered, encouraging marine innovation (1981:4). Whatever the case, in recent historical times, despite geographical and cultural barriers, nearly all societies indigenous to the archipelago have been involved in a complex network of trading and exchange relationships. "At the centre" of this network have historically been "...those who controlled the seas, integrating communities and regions" (Urry 1981:4).

Here it needs to be pointed out that, in addition to the role of the sea in communications, the Indo-Malaysian Archipelago is also singularly rich in marine life. While Island Southeast Asia, in terms of its terrestrial fauna, comprises a zone of overlap between Asian and Australian faunal zones, in terms of its marine fauna, it is, of itself, the single primary centre of world diversity. Thus as Dunn and Dunn (1984:252) observe, while

$[\mathrm{T}]$ he tropics are far richer in numbers of animals and plant species than are the temperate ... regions of the world, ...this generalization holds true for the seas at least as much as for the terrestrial realm ... [and o]f the tropical seas, ...those surrounding the mainland and islands of present day Southeast Asia are known to contain the greatest wealth of marine life ... The centre of this richness is Sundaic Southeast Asia, and Ekman's (1953:18) oft-quoted statement on this matter bears repeating here: "The further one moves away from this centre in any direction, the more the fauna appears as ... progressively impoverished...".

Much of this richness is due to the existence of two ecosystems unique to the tropics: coral reefs and mangrove associations (Dunn and Dunn 1984:252-253). In the next section, I will touch briefly on their significance to the development of maritime foraging in the region. But here the important point is that, from early times, large numbers of people in the Indo-Malaysian Archipelago have depended on the sea for their subsistence. If the early Austronesians entered the archipelago with an already developed maritime technology, it is likely that while some groups may have abandoned seafaring to concentrate on the land, others almost certainly responded to this richness by developing even more proficient fishing and strand-gathering technologies.

While trade was undoubtedly part of the resulting marine adaptations that evolved, the second point to be made is that not all of those who engaged in 
maritime trade occupied positions of economic or political dominance. Coastal fishing communities, while dependent on trade, have never enjoyed high status or notable power in Southeast Asia. The "oceanic nomads" who appear to have been instrumental in the formation of the earliest historical states in the region were in many cases semi-pariahs, some of whom maintained boat-nomadism, as we shall see presently, just as hunter-gatherers ashore preserved its forest counterpart, as a means of dissimilation, a way of resisting domination and the loss of identity to neighbouring land-based societies.

All of this should not detract, however, from Urry's main argument concerning the dominance of the sea, and so of trade in early Austronesian prehistory. Initially, before the development of navigational skills, the sea must have constituted a barrier to wider integration. Thus during this early period, a mosaic of cultures would have developed, occupying different environments, and it was this rich variety of environments and human cultures that provided, Urry (1981:7) argues, the basis upon which the trade and exchange of later periods developed. It also contributed to the formation of political hierarchy. Thus he maintains (1981:7),

the group or groups who gained some mastery of the seas and who could thus transform the barrier into a bridge, could exploit this cultural variety for their own ends. Indeed, if it were done carefully, they had the potential to dominate the whole archipelago.

The subsequent growth of trade did not spell an end to socio-cultural diversity. Indeed, as Urry notes, the experience in Southeast Asia has been that cultural distinctiveness is characteristically fostered rather than destroyed by trade. However, Urry argues that if one group dominates, then the danger exists that this domination may threaten the very diversity on which the system is based. This question of dominance and possible assimilation leads to Urry's major argument (Urry 1981:9) that the early Austronesians, even before they left eastern Asia, may have already been adapted to coastal conditions and to inter-island trade. Thus trade itself may have contributed to Austronesian expansion. Groups may have set out, in other words, seeking not only new lands to farm, but exchange goods and new communities to trade with (Urry 1981:9). As the Austronesians entered the archipelago, the geography of the region would have given a further stimulus to trade and to the development of maritime technology. Geography thus provided the "basic outline upon which ... the prehistory of the region [was later] played out".

The pattern of islands and inland seas provided the stimulus for maritime innovation and the production of goods from the ecological and cultural diversity of the islands supplied the impetus for trade and exchange. Utilizing sea routes the whole pattern of trade and exchange and the 
strategies for developing producers and consumers was expanded within and beyond the archipelago (1981:23).

Ultimately this expansion drew the Austronesians westward, throughout Island Southeast Asia to the mainland, and eventually to the Indian Ocean and beyond. ${ }^{2}$

As a result of their control of the sea, the first Austronesians were able to spread their culture and language, assimilating pre-existing populations through their command of maritime trading networks. An example is provided by the collectors-for-trade of southern Malaya whose assimilation we described in the previous section. Thus Urry (1981:10) argues that a mass movement of people is not necessary to account for the spread of Austronesian languages. Trade seems likely to have played a part in encouraging expansion, and once the Austronesians began to penetrate the Indo-Malaysian Archipelago, the subsequent spread of Austronesian languages is likely to have been linked to trade itself, with Austronesian languages replacing the earlier languages of the area through their role as the dominant languages of trade.

\section{Sea Nomads}

Whatever its role in Austronesian expansion, there can be little doubt that the sea has shaped, in a major way, the subsequent history of the Austronesian-speaking world. In Western Austronesia the sea and immediate littoral have also been, from the beginning of historical documentation, zones of notable economic and ethnic diversity, and have included within their compass widely-scattered communities whose distinctive mode of life is characterized by various forms of boat-dwelling nomadism - peoples constituting, in short, maritime foragers.

The Southeast Asian sea nomads are divided geographically, culturally, and linguistically into three major groupings, each the product of an apparently independent history of adaptation. The first of these groupings comprises the Moken and Moklen of the Mergui Archipelago of Burma, with extensions southward into the islands of southwestern Thailand (Anderson 1890; Hogan 1972; Ivanoff 1985, 1987). The second is represented by a congeries of variously named groups, collectively referred to as Orang Laut (lit. "sea people"), who inhabit the islands and estuaries of the Riau-Lingga Archipelagoes, the Bantam Archipelago, and the coasts and offshore islands of eastern Sumatra, Singapore, and southern Johor (Andaya 1975; Logan 1847; Sopher 1965; Wee 1985). A northern subgroup of Orang Laut, the Urak Lawoi, occupy the offshore islands from Phuket to the Adang island group, along the southern edge of the Moken-Moklen range (Hogan 1989:1-2). ${ }^{3}$ Finally, the third, and largest grouping consists of the Sama-Bajau, most of them maritime or strand-oriented communities, but including also small numbers of boat nomads, who together form what is probably the most widely-dispersed ethnolinguistic group 
indigenous to Island Southeast Asia, living over an area of some one-and-a-quarter million square miles, from south-central Philippines, eastern Borneo and Sulawesi, south and eastward through to the islands of eastern Indonesia to Flores and the southern Moluccas (Fox 1977; Geoghegan 1984; Nimmo 1972; Pallesen 1985; Sather 1975a, 1978, 1984, 1993a).

\section{The Sama-Bajau}

Here I begin with the last of these groupings, the Sama-Bajau, with whom I conducted fieldwork in coastal Borneo. ${ }^{4}$ The earliest mention of maritime peoples identifiable as Sama goes back to the 16th century. Today the Sama characteristically live in dispersed shoreline and island settlements, often surrounded and interpenetrated by those of more numerous land-based peoples. Everywhere the Sama lack political unity. In contrast to their politically-dominant neighbours, they identify themselves with a multitude of small, highly fragmented local groups, none of them sufficiently integrated or large enough to exist in its own right as an independent political entity. Most of these groups are distinguished toponymically by the name of an individual island or island cluster identified by its members as their homeland or principal area of settlement (Sather 1993b). The boat nomads are the chief exception. Without an exclusive land affiliation, nomadic groups characteristically identify themselves as the Sama Dilaut, the "Sea" or "Oceanic Sama" (Sather 1984:12-13, 1993a).

As a whole, the Sama are strongly associated with the littoral. In the Sulu Archipelago of the Philippines, where perhaps a half of the total Sama-speaking population lives, they predominate chiefly in the smaller coralline islands, particularly those of the northern, southern and western margins of the archipelago (Sather 1993b). On the larger, more heavily populated and mainly central islands, the Sama are greatly outnumbered by the land-based and predominantly agrarian Tausug. Historically, within the Sulu Sultanate the Sama formed a subordinate population. In the silasila, the Tausug genealogical histories of Sulu, the Sama are represented as the recently-arrived "guests" of ranking lines of local Tausug leaders (Saleeby 1908:156-157), a representation that reverses, as we shall see, their actual historical relationship. Traditionally, power in Sulu was based on factional politics, and local leaders, both Tausug and Sama, were joined in a loose, pyramidical network of personal allegiances that ran from village headmen and local title-bearing chiefs to the sultan at the apex of the political order (Kiefer 1972; Sather 1984:3-8).

Tributary trade was a central feature of the Sulu state. Power derived from control over trading commodities and the people who procured them. Thus, the sultan's authority was sustained by a procurement economy, articulated through personal patronage and alliance, in which labour and locally-produced commodities of trade were supplied by a variety of differentially adapted ethnic and sub-ethnic communities, including local bands of boat nomads. Within the 
archipelago, trade was the single unifying principle, welding together people in what was otherwise a zone of enormous cultural and linguistic diversity (Sather 1985:168-175; Warren 1979).

Through this system of procurement, shore-based Sama provided their local patrons with services as skilled seamen, boat-builders, smiths, artisans, mat-makers, potters, fishermen, and inter-island carriers and traders, while the most prestigious and independent of these groups, such as the Balangingi Sama, supplied maritime raiders and procured slaves for the Tausug markets of Jolo (Sather 1984, 1985, 1993b; Warren 1978, 1981). ${ }^{5}$ The boat nomads, who lived in scattered bands throughout the whole of Sulu, formed, together with swidden cultivators inhabiting the coastal fringes of Mindanao and eastern Borneo, the least prestigious and lowest ranking of these groups. Historically the boat nomads acted chiefly as divers and specialized fishermen, procuring for their land-based patrons a variety of important commodities of trade, including, in the eighteenth and nineteenth centuries, tortoise-shell, tripang, pearls, dried fish and pearl-shell (Sather 1984, 1993a; Warren 1981:60-61). Although the boat nomads formed only a small minority of the islands' population, these commodities represented in the past a major source of Sulu's export wealth.

Lacking a territorial identity, the sea nomads, in contrast to other Sama, were without formal jural status in the Sulu Sultanate (Sather 1984:15). Among them, characteristically, each boat housed a single family. Local bands were comprised of families that regularly anchored together at the same moorage site (sambuangan), or at the same seasonal sites, mooring their boats in smaller family alliance groups (Sather 1985:190-194). While at anchor, family members repaired and careened their boats, traded and engaged with others in an intense round of social transactions (Sather 1976, 1984:12, 1985:171). Each local anchorage group was under the protection of a recognized leader ashore whose land-based followers enjoyed a privileged trading relationship with its members. In the past, at every level of the alliance hierarchy, individual leaders, from village headmen to the sultan, maintained armed retinues (Kiefer 1972). In a setting of endemic factional violence, rivalry and armed feuding, nomadic bands depended for their physical security on their patron's protection (Sather 1984: 14-15). Although patrons described "their" boat-nomadic clients as "property" (Sather 1984:14), these local groups were able to move relatively easily from the territorial sphere of one leader to another, and so had to be treated with some care for fear of losing their trade to rivals (Sather 1971, 1984:13-15).

Kemp Pallesen (1985) has proposed a model for the historical dispersion of the Sama-Bajau, based on a linguistic reconstruction that, extending over a millennium, highlights the role of trade and political relations in the development of maritime adaptations, including boat nomadism. 
Sama-Bajau language relations are reconstructible only to the first millennium AD. Beyond that, wider affiliations are problematic (Pallesen 1985: 117). ${ }^{6}$ By AD 800 speakers of Proto-Sama-Bajau were established in the area surrounding Basilan Straits, in the northern islands of the Sulu Archipelago and along the adjacent Mindanao coastline (Pallesen 1985:117). Language reconstruction indicates that these people were predominantly sea-oriented, but not exclusively so. Thus, evidence also points to a long familiarity with farming, iron-forging, pottery-making and weaving. Although their knowledge of the sea was more intimate than of the land, the early Sama were, by no means, a population made up entirely of boat nomads and fishermen. Instead, a marine orientation coexisted with "a significant and coherent tradition of land-oriented activity" (1985:255), indicating the presence,

... already at this predispersion time [of] a divergence of orientation between the land and the coastal strands ... (Pallesen 1985:117).

Reflecting this divergence, different Sama groups, from the beginning, appear to have pursued, much as they do today, various permutations of this "dual orientation", some focusing on the land, others on the strand or sea, with communities of sea nomads forming only one of a multitude of economically diverse groups (Pallesen 1985:118).

The ethnography of the Sama-Bajau is fully consistent with this reconstruction. Not only do boat-nomadic groups comprise only a small minority of all Sama-speakers, ${ }^{7}$ but everywhere they exist within a larger cultural and linguistic matrix that includes closely related shore- and land-based communities.

When I began fieldwork in southeastern Sabah in 1964, some families making up the local community were still boat-dwelling, while others had begun a short time earlier to erect a pile-house village over the community's principal moorage site (Sather 1984:20; 1985:173-176). The community itself, however, remained largely nomadic. Thus its families continued to move between the site and dispersed over an extended fishing zone surrounding it (Sather 1976; 1985: 187-190). Although some, particularly younger, men were beginning to seek wage-work ashore, the community as a whole remained overwhelmingly maritime and entirely non-agricultural, without crops or landed property. Yet, within the community, there existed a tradition of myths in which the narrative heroes practised swidden rice-cultivation, with the myths themselves giving a technically detailed account of swiddening (cf. Sather 1975b). In addition, mediums (jin) conducted an annual trance-ritual called magpai baha'u in which conical mounds of "new rice" (pai baha'u) were shaped into symbolic "mountains" (bud). Thus, while the Bajau Laut did not themselves farm, rice and its cultivation, nevertheless, formed an integral part of the community's mythic and ritual vocabulary. 
At one level, this example might be taken as a cautionary case, illustrating the danger of reconstructing the economy from the evidence of language alone. Yet at another, and perhaps more significant level, it can be said that the boat nomads, although non-cultivators, participated in a larger cultural and cognitive universe in which rice-cultivation is both present and familiar. The surrounding islands and coastline are relatively populous, and coastal and shoreline Sama villages, many of them agricultural, are seldom out of the sight of Bajau Laut fishing parties. Thus, farming is not unknown, even to the most sea-oriented Sama. Moreover, as I have described elsewhere (1984:10-11), all local Sama communities, whether sea nomads or shore-oriented groups, were historically enmeshed in a regional network of symbiotic exchange. Thus, for example, in addition to farming, some Sama communities in Semporna produced pottery for trade, including earthenware hearths carried by sea nomads aboard their boats; others offered iron-work, tortoise-shell jewellery and skilled carpentry; or supplied caulking resins and kajang-roofing for boats (Sather 1984:11). Locally, each of these groups constituted a named dialect community. Linguistically, each community was, and continues to be, aligned with others in continuous dialect chains. Thus, in any one region, interacting Sama, both at sea and ashore, speak mutually intelligible dialects, at once understandable, yet readily identifiable by community affiliation. Within this enmeshing network, exchange and regular contact, while fostering economic specialization, prevent groups from undergoing total dissimilation, ensuring instead that they all share in a common language and cultural tradition.

Pallesen (1985:118), in his reconstruction, sees the 10th century as the beginning of a major period of Sama dispersion. Thus, a number of sea-oriented groups probed northward, establishing ports of call around the eastern coast of Mindanao and beyond. Others settled the broad zone of mangrove swamps at the head of Sibuguey Bay. At the same time a third group, the Yakan, located on Basilan Island within the original Sama-Bajau homeland, became linguistically and socially distinct, not by sea-going migration, but, on the contrary, as a result of territorial stability, by intensifying its land-orientation, shunning the sea and becoming a settled group of inland swiddeners (Pallesen 1985:118). Today dissimilation is so complete that the Yakan are generally accepted as a separate ethnolinguistic group, distinct from other Sama-speakers (Frake 1980:325-326). Later, in the eleventh century additional sea-oriented groups spread southward, down the Sulu Archipelago. One branch eventually settled the northern and western coasts of Sabah (Sather 1993b). Another established itself along the southeastern coast of Sabah, and from there its forward advance reached the Straits of Makassar, entering eastern Indonesia some centuries before the first European penetration of the region (Fox 1977).

The turn of the millennium thus marked the beginning of a long period of Sama movement. In addition, some 700 years ago, the Sama came into first contact 
with the Tausug. Pallesen (1985:246-247) argues that these two events were related and that changing economic and political relations were the catalyst of both. Underlying these changes was long-distance trade with China, India and the Middle East. Pallesen (1985:247) suggests that the Sama, in probing northward, established a network of trading colonies along the rivermouths and coastlines of the islands they encountered, including Mindanao. This development, while commercial in motive, did not necessarily entail elaborate enterprise. Instead, Pallesen (1985:248) suggests,

... a major early element of ... trade may well have been the protein-starch exchange which underlies much economic activity in Sulu [to the present].

Salt fish is today the major source of protein for inland peoples in the Philippines and northern Borneo and dried fish has been, throughout historical times, a principal item of trade for Sama-speaking peoples and the major export commodity of Sulu. ${ }^{8}$ Pallesen argues that this protein-starch exchange was probably a major factor in the early dispersion of the Sama. But once they had established a network of scattered bases, they were then well-positioned to take advantage of further trading developments. Thus Pallesen (1985:249) writes:

The maritime skills of [the Sama] and the wide distribution of their settlements or ports of call would have given them an advantage in exploiting the growing trade opportunities in the centuries around 1000 AD.

By the eleventh century, Jolo Island, located at the centre of the Sulu Archipelago, emerged as the hub of this network and the primary entrepot for the whole of the archipelago.

Pallesen argues that this spread of Sama colonies brought Sama-speaking traders into contact with the ancestors of the Tausug. Linguistically, Tausug is a Southern Central Philippine language. Its nearest sister language is Butuanon, spoken today in a limited area at the mouth of the Agusan River in eastern Mindanao (Pallesen 1985:125ff). Pallesen considers it probable that Sama traders established an early colony here, in order to command the local river trade, and that, through intermarriage, some returned to central Sulu, taking with them Tausug women and children. According to Pallesen (1985:265), the present Tausug population thus had its genesis in a bilingual trading community established chiefly at Jolo by Sama traders and their Tausug-speaking wives and children.

By the time this bilingual community took form, Jolo was already a major commercial centre with links to China, the central and northern Philippines, Borneo, and to other parts of the eastern and western Malay world. Taking advantage of its strategic location, this Jolo-based trading élite gained power 
and numerical strength, using its power not only to maintain Tausug as a distinct language, but to absorb the more settled land-based Sama then present in the larger central islands of Sulu, assimilating them linguistically and culturally. This process of assimilation continues to the present. Economic differences were thus accentuated and the remaining Sama came to be increasingly associated with the peripheral islands of the archipelago and with the more maritime sectors of Sulu's economy.

With the coming of Islam, and the emergence of the Sulu sultanate in the 14th century, the Tausug assumed formal dominance over the other peoples of the Sulu Archipelago, most of them Sama-speakers. In the process the Tausug evolved a distinctive ethnic identity by way of sealing their political and economic domination, and with the rise of the Sulu Sultanate, differences of rank, religion and power came to assume ethnic characteristics (Frake 1980; Sather 1984).

The sultanate, with its defining features of political and religious hierarchy, constituted an ethnically segmented state, with political allegiance, rank and religion all united in a single, all-embracing system of ethnic stratification (Sather 1984:3-8). Thus the Tausug, concentrated in the larger central islands of the Sulu Archipelago, where the power of the state was strongest, formed its principal agrarian population, its chief traders, and through their monopoly of aristocratic titles, the holders of its most powerful political and religious offices, including that of Sultan. By contrast, the Sama, and above all the nomadic Bajau Laut, were identified with the margins of the state, its territorial peripheries, the sea and shoreline, political clientage, lesser degrees of religious piety, and in the case of the boat nomads exclusion from the Faith altogether, as non-Muslims (Sather 1984:13-15).

Outside of the Sulu Archipelago, the southward spread of Sama-speakers throughout eastern Indonesia appears to have similarly preceded the rise of commerical polities. Again, the emergence of regional trading states marked the subordination of Sama mariners and fishermen, and the related development of maritime trading networks, in particular the tripang collecting industries organized under Makassar and Bugis patronage, followed closely patterns of Sama dispersion and voyaging (Fox 1977; Pelras 1972; Reid 1983:124-129).

For the Bajau Laut, sea nomadism existed, then, in a context of states and trade, including both symbiotic trade and politically-structured tributary trade directed toward international markets (Sather 1985:168-175). The boat nomads, as we know them from the nineteenth and early twentieth centuries, practised a complex, highly specialized adaptation and in no sense can they be described as "primitive" foragers. In this regard, Bellwood (1985:136) is almost certainly right to regard their way of life as a comparatively recent development. 
On the other hand, it should not be forgotten that, among the Sama as a whole, communities of boat nomads appear to have emerged out of a larger, more highly diverse island and coastal population. It seems probable that boat nomads everywhere in Southeast Asia evolved from a similar matrix, appearing originally as generalized coastal foragers, but becoming increasingly specialized and trade-dependent with the rise of maritime states, a development to which their presence itself almost certainly contributed.

Through trade and political clientage, the Bajau Laut appear to have become not only trade-dependent, but also increasingly specialized in an ecological sense. Two major sources accounting for the richness of marine life in the Indo-Malaysian Archipelago are, as we noted earlier, its coral reefs and mangrove forests, both of which are unique to the tropics and particularly well-developed in Island Southeast Asia. Other littoral environments such as sandy or rocky shores are essentially the same as in other parts of the world. Each of these environments has a distinctive biota. However, as Dunn and Dunn (1984:254) observe:

two or more such biotypes may occur together or within a small area. For example, a coral reef may fringe any type of shore, and rocks may occur in the midst of sand beaches. Such areas have a greater variety of species than has each biotype alone, and for that reason it is likely that mixed environments would be preferred as subsistence zones by peoples who exploit marine resources.

Indeed, most sea nomadic communities exploit an extended range of habitats, typically incorporating a variety of biotypes (cf. Sather 1985:183-190). However, most contemporary communities tend to concentrate on one or two primary ecosystems. Thus, in southeastern Sabah, the Bajau Laut focus most of their fishing activity on coral reefs, submerged coral terraces, associated sandy beaches and tidal shallows. They make little use of mangrove shores, except to take firewood, and avoid altogether muddy or turbid waters. Cultivated foodstuffs are obtained entirely by trade. In contrast, some Orang Laut communities, such as the Duano of east Sumatra (Sandbukt 1984:10), occupy areas of brackish mudflats and mangrove swamps and have developed a highly specialized foraging adaptation that utilizes the extremely narrow but rich resource base represented by this particular environment. As with the Bajau Laut, such specialization does not permit economic self-subsistence, and in return for littoral produce the Duano obtain virtually all of their other necessities from trade with riverine Malay horticulturalists, including cultivated foodstuffs and even their dwelling-boats.

Such specialized adaptations appear, however, to have developed from a more generalized pattern of coastal foraging. Evidence of such an early pattern has recently come to light from Bukit Tengkorak in southeastern Sabah (Bellwood 
1989; Bellwood and Koon 1989). Here archaeological materials reveal a population living during the first millennium BC in a coastal setting, heavily exploiting the area's marine resources and engaged in long-distance sea trade, while at the same time exploiting also the nearby streams and coastal forests. Perhaps the most intriguing feature of this site is the presence of portable pottery hearths. These hearths, carried on boats, have historically been the hallmark of boat nomads and related maritime Sama in the region. Thus there may be a suggestive link here to the possible precursors of the later sea nomads in the region.

With the dissolution of the Sulu Sultanate, and the breakdown of procurement trade and its replacement by a monetized market for fish and other maritime products, the specialized adaptation of the Bajau Laut also broke down, leading in this century to an almost complete disappearance of boat nomadism and to the settlement of formerly nomadic communities in permanent strand villages (see Nimmo 1972; Sather 1984, 1993a; C. Warren 1983).

\section{The Orang Laut}

Although culturally and linguistically very different, the situation of the Orang Laut, as we know it from the 16th through the end of the nineteenth century, was in many ways similar to that of the Sama-Bajau. Even more than Sulu, the Straits of Malacca, along the southern approaches to which the Orang Laut were very largely concentrated, were and continue to be a major cross-roads of maritime commerce. They were also the primary arena of Malay political history. Thus historians like Wolters $(1967,1979)$ on Srivijaya and Andaya $(1974,1975)$ on the Johor Kingdom have stressed the centrally important role they see the Malay-speaking Orang Laut as playing in providing the naval power and communicative links on which the hegemony of successive Malay states was based in a zone of otherwise relatively sparse population. Here, like Sulu, the sea nomads similarly emerged, together with a variety of related coastal and strand peoples, from a common cultural matrix.

With the Orang Laut, we see boat nomadism, again, embedded in a complex political order. In the seventeenth and eighteenth centuries, for example, different named groups of Orang Laut were incorporated in the Kingdom of Johor by their formalized ties to the ruler (Andaya 1974). These ties were articulated in terms of the specific corvée duties assigned to each of these groups (or suku). With corvées were associated degrees of status. Thus Andaya (1974:7), writing of the seventeenth century, outlines these relationships in the following terms:

The more powerful and prestigious Orang Laut groups were associated with the larger islands or those islands which were favourably situated on major sea trading lanes, ... The duties of the Orang Laut were to gather sea products for the China trade, perform certain special services for the ruler at weddings, funerals, or on a hunt, serve as transport for envoys 
and royal missives, man the ships and serve as a fighting force on the ruler's fleet, and patrol the waters of the kingdom. Except in times of actual warfare when their services were needed for the fleet, the Orang Laut were usually on patrol providing protection for Johor's traders or to those wanting to trade in Johor while harassing all other shipping.

Groups such as the Orang Suku Galang, for example, comprising the upper stratum of Orang Laut, were those whose duty, as might be expected, was to provide the naval fighting force for the realm. In contrast, the corvée duty assigned to the Orang Mantang, who formed one of the lowest status groups, was to care for the ruler's hunting dogs. Later, with the breakdown of central hegemony, fighting groups like the Orang Galang appear to have transferred their allegiance to local Malay chieftains who engaged them as pirate crews. As a result, one of the consequences of the suppression of piracy in the mid-nineteenth century was a rapid sedentarization of a number of these Orang Laut groups (Sandbukt 1984:7; Sopher 1965). Today, former high status groups have generally embraced Islam and become more or less assimilated into the general Malay population, while marginal low status groups have generally continued to maintain a separate ethnicity, even after becoming sedentary fishermen.

Like the Bajau Laut, the identity and mode of life of the Orang Laut was powerfully shaped by their interaction with settled groups in a larger, hierarchically-constituted field of political and economic relations. Both groups lacked an independent political and economic existence, separate from that of their settled neighbours. Within the Malay world, this interaction appears to have been even more formally structured than it was in Sulu, where the sultanate remained, despite its formal patterning on a Malay court model, a relatively loosely structured polity (cf. Kiefer 1972). Thus the Orang Laut were divided, through their relationship to the ruler, into status groups, each differentially situated to perform specific corvée tasks, these tasks in turn associated with positions in an almost caste-like status hierarchy. To the extent that the Orang Laut functioned as marine foragers and fishermen, they were clearly, like the Bajau Laut, "professional" foragers whose very existence presupposed trade, political hierarchy and the institutions of the state.

\section{The Moken}

In comparison, the Moken offer an important contrast. If Bukit Tengkorak suggests that boat nomadism may have evolved from a more generalized form of coastal foraging, the Moken give evidence of what such an adaptation may have been like. Unlike Sulu, and even more the Straits of Malacca, the Mergui Archipelago was a comparative backwater in the past. Here boat nomads, while trading with shore people for agricultural produce, appear to have been much 
less subject to their political domination and were little involved in a procurement trade for external markets. Mergui therefore presents us with a form of boat nomadism as a predominantly subsistence adaptation.

Fortunately for the Moken, unlike the Bajau Laut and other boat nomadic groups, we have a comparatively detailed ethnographic literature for the late nineteenth and early twentieth century (cf. Anderson 1890; Carrapiett 1909; White 1922). While the Moken also gathered some marine and littoral produce for exchange, receiving in return cultivated staple foods such as rice, this trade was mainly seasonal and for most of the year Moken bands appear to have been largely self-sufficient. Some groups in addition planted shoreline gardens, to which they returned from time to time to harvest crops. In contrast to the Bajau Laut, the Moken made extensive use of the resources available in the interior of the larger islands of the archipelago. Here they gathered wild honey, fruit, roots and tubers and hunted wild pigs with the aid of dogs. Some communities also occupied brackish tidal estuaries and mangrove swamps, exploiting these areas, not in the highly specialized manner of the Duano, but as one of a number of varied foraging habitats.

Today many of these groups, much like rainforest hunter-gatherers, are faced with environmental loss as mangrove and coastal forests are cleared for farming, charcoal production, plantations and other kinds of coastal development (Engelhardt 1987:11-13). Thus, many former boat nomads in southwestern Thailand have been forced into an increasing reliance on inshore fishing, where they face competition and, increasingly, assimilation by established coastal populations.

From this survey it should be clear that an understanding of boat nomadism requires that it be seen historically and in a wider ecological context. As Sandbukt (1984:4) stresses,

Because of their dispersal $\ldots$ and the varying extent and significance of their historical interaction with land-based peoples, a comprehensive study of the sea nomads necessitates a region-wide perspective and one with a considerable timedepth, in addition to localized field studies.

When viewed from such a perspective, the sea nomads may be seen as associated with archipelagic environments that are, in the western Austronesian world, singularly extensive and rich in food resources. Implied is a wealth of opportunities for strand foraging and for the exploitation of inshore waters using nets, spears and other techniques, all historically employed by the sea nomads (cf. Sopher 1965). But also implied is access to the shoreline and to coastal forests which hold out still further exploitable resources, including wild plant foods capable of supplementing a protein-rich marine diet. What is suggested is a range of possible adaptive modes, and among them the possibility of a more 
generalized adaptation, resembling more closely hunter-gathering (rather than peasant fishing), in the sense that it involves the exploitation of a highly diverse resource base. This possibility is obscured in the case of the Sama and Orang Laut by their specialized adaptation to trade and the state.

Finally, while the role of maritime peoples in early Austronesian expansion remains unclear, Solheim $(1975,1984)$ has recently proposed that this role was possibly central and that it may have involved peoples ancestral to the historical sea nomads. As an alternative to the model of southward migration proposed by Bellwood and others, Solheim (1984:86) has argued that the proto-Austronesians first emerged within Island Southeast Asia itself. In this thesis, he proposes that Austric, a possible language grouping encompassing both Austroasiatic and Austronesian, was spoken throughout the whole of Southeast Asia, including Sundaland, during the late Pleistocene (Solheim 1975:152). Later, with raising sea levels, Sundaland became a zone of islands, isolating Austric speakers in the east from those of the west and north, and so producing a split between what he calls "Pre-Austroasiatic" speakers on Sumatra and the Southeast Asian mainland and "Pre-Austronesian" speakers in eastern Indonesia and the southern Philippines (1975:156). Following this split, Proto-Austronesian developed according to Solheim in Island Southeast Asia and from there was carried northward to Taiwan and South China by a developing maritime people whom he calls the "Nusantao" ("people of the island homeland") (1975:156-158).

In a more recent version of this hypothesis, Solheim (1984:81) proposes that Proto-Austronesian developed initially as a "barter language" among these early "Nusantao" mariners, who came eventually, following their northward migration, to occupy the coasts of northern Luzon, southern Taiwan and South China some time between 4500 and 5000 BC. Later Taiwan became isolated, while elsewhere along the western shores of the South China Sea, developing Austronesian languages remained in contact as a result of "Nusantao" voyaging and so diverged only much more slowly from one another. Following the isolation of Taiwan, the resulting "Proto-Malayo-Polynesian" languages were then carried southward, back through the Philippines to Borneo and from there south, east and westward, by groups of bartering "Nusantao" mariners (1975:153; 1984:84-85).

While many elements of Solheim's hypothesis appear improbable, particularly, his account of the emergence of Proto-Austronesian, his arguments have the merit of highlighting the possible role of sea-going trade and maritime peoples in early Austronesian expansion. Indeed, Solheim sees the historical sea nomads as representing "the most direct descendants" of his "Nusantao" mariners, although,

During the last few hundred years their status has deteriorated, bringing them to the bottom of the local pecking order instead of being, as they 
were around 2000 years ago, economically prosperous and the masters of their homes and livelihood, the southern and eastern seas, from Madagascar to Japan to Easter Island (Solheim 1984:86).

Here Solheim perilously telescopes a vast sweep of Southeast Asian and Pacific prehistory; he also ignores the apparently diverse origins of the sea nomads themselves and the existence of close cultural and linguistic affinities between them and related shore- and island-peoples, all suggesting a long and complex pattern of local interaction.

\section{Forest Foragers}

Today, contemporary hunter-gatherers in Island Southeast Asia are associated primarily with the equatorial rainforest, an ecosystem that is believed to have expanded in the region around 10,000 BP, replacing in many regions monsoon forests and parklands (see Bellwood 1985:31-36). It is, as yet, unclear when Southeast Asian foragers began to exploit the equatorial rainforest. As indicated earlier, some have argued that this may not have taken place until after cultivated foods became available and the rainforest itself was modified as a result of agricultural clearing (cf. Headland 1987; Bailey et al. 1989; Peterson and Peterson 1977). The details of this argument are beyond the scope of our discussion here, but basically the contention is that "undisturbed" equatorial rainforest lacks an adequate resource base, particularly in starch foods, to support an independent foraging economy, a contention that is open, as we have seen, to serious question (see Brosius 1991; Endicott 1984; Endicott and Bellwood 1991).

For Borneo, Blust (1989) has argued on linguistic grounds that present-day foragers, being Austronesian-speakers, are the descendants of past cultivators. Similarly, Hoffman $(1984,1986)$ maintains that Bornean foragers are "secondary hunter-gatherers" whose ancestors were former horticulturalists who moved into the forest in order to specialize in the collection of forest products for trade. Harrisson (1949) and Seitz (1981) make similar arguments. However, anthropologists working with contemporary foraging societies in Borneo have disputed these views, particularly those of Hoffman, doing so on both conceptual and empirical grounds (cf. Brosius 1988, 1991; Nicholaisen 1976a; Sellato 1988, 1989). Without denying the significance or long history of trade in forest products, or the close economic ties that typically exist between foragers and surrounding cultivators, most have stressed the lack of a precise time-frame that tends to characterize many of these "devolution" arguments. Thus, Sellato (1989:6) notes that there are no recorded instances in Borneo of horticulturalists having become forest nomads. Instead, over the last two centuries, the observed movement has been entirely in the opposite direction, with virtually all foraging groups adopting some elements of cultivation and sedentism. 
Linguistic evidence, although incomplete, also fails to support a notion of recent "devolution". Hoffman (1986:14-15) argues that adjacent, trade-connected foraging and agricultural groups speak "nearly identical languages". This, however, is not the case (cf. Brosius 1988:83-84). In Sarawak, for example, the principal foraging population, the Penan, is divided between two dialect groups which Needham (1972:177) calls the Eastern and Western Penan. Although distinct, dialects of both groups are mutually intelligible. In contrast, the settled agriculturalists with whom these groups regularly trade belong to at least twelve different language families (Brosius 1988:84). Thus, while the Penan show some degree of linguistic unity, no close linguistic relationship has yet been demonstrated between them and other major foraging populations in Borneo. Instead, the Penan are linguistically related to the Kenyah, a diverse collection of swidden cultivators. While the present Penan may thus have "devolved" from Kenyah cultivators in the past, the situation is complex, as ethnohistorical evidence strongly indicates that at least some Kenyah have adopted agriculture relatively recently as a result of contact with an expanding Kayan population (Rousseau 1990:245-246). A much stronger probability therefore exists that many, if not all, Kenyah were, like the Penan, rainforest foragers in the past (Rousseau 1990:246).

With regard to nutritional arguments, the debate concerning rainforest foragers has centred chiefly on wild yams (cf. Headland 1987). In Borneo, however, the principal source of dietary carbohydrate is not yams, but rather the starch of the wild sago palm (Eugeissona utilis). Dependence on wild sago not only sets Borneo foragers apart from other Southeast Asian hunter-gatherers, but seriously challenges the more general nutritional arguments against independent foraging (Brosius 1990, 1991). Closely related to this, a second feature which

distinguishes Penan (and other Bornean foragers) from those elsewhere in Southeast Asia, ...is that whereas groups such as Agta and Semang live and forage in close proximity to agricultural settlements, Penan inhabit areas in the deep interior, usually one to four days' walk from the nearest agricultural settlements (Brosius 1991:136).

This is not to say that they live isolated from contact or trade with neighbouring longhouse people. On the contrary,

trade is of vital importance to Penan. However, unlike most other tropic foragers, ...trade does not involve the exchange of forest products for food. Penan trade various forest products for items such as tobacco, metal, cloth, salt, and flashlight batteries, but not for food items ... With respect to food, [they] are wholly self-sufficient ... (Brosius 1991:136). 
Here, as Brosius (1991:130) notes, contrary to assumptions made regarding tropical foragers elsewhere (cf. Bailey et al. 1989:64), the existence of a vigorous, long-established trade with settled agriculturalists does not, in itself, rule out the possibility of subsistence independence.

The Eugeissona palm on which the Penan and other Bornean foragers depend occurs throughout the interior of central Borneo, at a wide range of elevations, but is found in greatest concentrations on steep ridges and slopes, where it grows in dispersed groves interspersed with other forest vegetation (Brosius 1991:146). While we lack detailed quantitative data on nutrition and production, Eugeissona is known to be a rich source of carbohydrate and studies indicate that its starch is high in energy (350-400 kilocalories/gram) (Sellato 1989:159). Although much smaller than cultivated sago (Metroxylon), a single trunk yields, on average, about $4 \mathrm{~kg}$ of starch, ${ }^{9}$ roughly enough to feed a single adult for a week (cf. Sellato 1989:159-60; also Anderson et al. 1982; Kedit 1982). To feed a band of 20-50 persons requires a weekly felling of some 15 to 20 palms.

Wild Eugeissona grows in dense clumps of some 3 to 6 trunks per clump, raised on a mass of aerial roots. While Borneo foragers vary considerably in social organization and settlement, basic subsistence patterns are notably similar. Typically, in processing palms, the men first fell 2 or 3 mature trunks from each clump, cutting the logs into sections, which are then carried to a stream or other water source, where the pith is reduced to flour (Langub 1989:175). This the women wash to extract the starch. Brosius $(1986)$ and Langub $(1988,1989)$ have both shown how, in the case of the Penan, methods of sago extraction are designed not to interfere with the palm's natural regeneration. Thus the Penan cut only a small number of mature trunks from a single clump, never felling the entire root-stock, thus leaving the clump to sprout new trunks. In this way stands are regularly harvested on a sustained basis. After the mature sago (nangah) has been cut, the remaining young sago (uvud) is marked (molong) (Langub 1989:174-176). The group then moves on to a new stand of palms where the process is repeated. After 2 or 3 years, the marked trunks are mature enough to be felled and the group returns to the original stand where the individuals who marked them now claim the mature trunks for processing into starch. Thus local groups orient their movements around known palm-stands. In doing so, they follow a pattern of regular rotational re-use not entirely unlike the fallow-rotation pattern practised by established swidden cultivators with regard to parcels of secondary forest (Sather 1990). ${ }^{10}$ The entire cycle extends over 5 or 6 years. By marking young sago, families secure for themselves rights of future harvest. These rights are respected not only within the owner's band, but between neighbouring Penan groups as well. A similar system of marking also applies to rattan, the principal item of Penan trade with outsiders. By means of this system, an orderly supply of sago, rattan and other items is thus assured and the principal 
forest resources on which the Penan depend are managed in a way that avoids their depletion or overuse (Brosius 1986, 1990; Langub 1988, 1989). ${ }^{11}$

Brosius (1991:131-132) sees in this pattern of management an important point regarding the nature of foraging generally. Foraging and agriculture are commonly treated as dichotomous modes of subsistence. "Yet", as Hutterer (1983:172-173) notes,

farmers also harvest what nature produces. [And while] It is true that agriculturalists manipulate the environments from which they derive their food ... so do hunters ...

In the case of the Penan and other Borneo foragers, this manipulation significantly affects the long-term availability of the forest resources these groups exploit (Brosius 1991:131). Farmers are not alone in modifying their environments. For the Penan, too,

the effects of past human exploitation [bear directly] on the present abundance of resources. Penan actively manage the Eugeissona palm, and their exploitation of this resource has a further impact on [its] demography (1991:146).

With an increasing availability of cultivated foods, foragers like the Penan, Brosius observes, may abandon their traditional management of forest resources. This, together with a loss of prime habitats to agricultural settlement, may make these resources less available. As a consequence, they may

drop out of the subsistence repertoire because their management is abandoned ... Thus, contrary to the assumption that hunter-gatherers could only have occupied tropical forests with the advent of agriculture,

it is possible, Brosius (1991:133) argues, that the introduction of

agriculture itself [may have] led to the current dearth of carbohydrate resources in most tropic forest ecosystems.

Sellato (1989:154-155) argues, too, against a radical dichotomization of foraging and agriculture, noting that questions regarding the origin of Bornean foragers have been founded conceptually upon just such an opposition. By accepting this dichotomy, observers have been prevented from seeing that the result of interaction between foragers and settled food-producers has been the emergence in Borneo of relatively stable societies combining features of both lifestyles, not of short-lived communities representing "intermediate stages" of either "evolution" or "devolution". Thus, today while foragers may be in the process of becoming sedentary, the end result is by no means a complete conversion to cultivation, much less to full-time rice-agriculture. Instead, partially settled foragers usually continue to forage, often, in fact, intensifying their collection 
of forest products as they take up part-time cultivation for subsistence. The reason, Sellato (1989:215) argues, has to do with the importance of trade itself as a social and economic relationship.

Here, it is possible to go even further and to point out that the great majority of Bornean foragers today are neither fully nomadic nor permanently settled (Langub 1989:172). While sedentism is relatively recent for many, Bornean foragers have long displayed marked variation in social organization and settlement forms. Thus, in Sarawak, the Western Penan work sago in large task groups, while the Eastern Penan process it in smaller groups (Brosius 1990: 7). Correspondingly, Western Penan bands represent highly enduring social aggregates, characterized by long-term population stability, not the fluid social groupings generally associated with hunter-gatherers. Reflecting this stability, the Western Penan maintained what Brosius (1986:176) describes as a "two-tier settlement pattern", consisting of a main settlement, called the lamin jau, and a series of impermanent satellite camps, the lamin tana, located close to the sago stands in which families are currently working. Today, this "two-tier" system has proved highly adaptable to semi-sedentarism, including continuing forest collection-for-trade, with permanent settlements - villages and longhouses now taking the place of the traditional lamin jau (Brosius 1990:4).

Similarly, upland cultivators in Borneo engage in substantial hunting, gathering and fishing, particularly in areas of expansive forest-pioneering. Here, especially in migratory situations where swidden cultivation is used as a pioneering technique to open tracts of primary forest to clearance and permanent settlement, upland cultivators enjoy both greater opportunity to forage and an increased need to retain foraging skills for survival. For the Iban, a major upland population of west-central Borneo, a significant attraction of primary-forest pioneering is the opportunity it affords for taking game, freshwater fish and wild plant foods. On the other hand, clearing the primary forest is a risky and arduous task, even with metal tools. As a result, in settled areas, as established swiddeners, the Iban, like other rainforest cultivators in Borneo, prefer to re-use the secondary forest well before its full natural succession in order to avoid the larger amounts of labour required to fell fully mature forest. Many also, like the Penan, manage stands of Eugeissona, both wild and planted, particularly in areas of pioneering where new and unfamiliar terrain is being brought under cultivation, as a famine food against possible crop failure.

In a more general way, it seems likely that the early Austronesians, too, as they spread southward through the Indo-Malaysian Archipelago, made similar use of foraging, particularly in extending their settlement into forested environments. Indeed, Austronesian expansion may itself have temporarily increased the value of foraging as an adjunct to agriculture. Secondary foraging may also have played a role in the domestication of new cultigens. It seems 
unlikely that groups narrowly focused on intensive rice agriculture would have been as inclined as those who continued to practise at least some secondary foraging to explore the wild plant resources of the new environments they came to occupy and incorporate not only new plant crops, but also, in the case of palm and tuber crops, new modes of husbandry and propagation. Finally, the early Austronesians, by enveloping foragers in a diversified economy, almost certainly made available technological innovations that rendered hunting and gathering itself more effective (Nicholaisen 1976a, 1976b). Thus, in Borneo, the Western Penan were well-known in the past as skilled iron-smiths (Needham 1972:178). Yet iron-working derived originally from surrounding cultivators. In adopting it, the Penan used iron to produce spears and drill-bits with which to bore hardwood blowpipe shafts. The use of spears and blowpipes both enormously enhanced the effectiveness of hunting and so the productivity of rainforest foraging itself as an economic option (Brosius 1990:5-6).

In other ways as well, the dichotomization of foraging and cultivation may be misleading. Thus, subsistence systems in Borneo show a continuum of stable combinations of rice agriculture, domesticated sago and tuber cultivation, orchard crops, forest foraging, hunting, fishing and marine collection. Rice itself is grown by means of an almost infinite variety of methods. Upland peoples are often characterized as swidden cultivators. However, in Sabah and northern Sarawak many practise irrigated forms of cultivation, some of which are highly distinctive (cf. Talla 1979:309ff.), suggesting a long history of local development. Similarly swidden systems are themselves diverse, not surprisingly so considering the great variety of terrains and cultural settings in which swiddening is practised. Moreover, swidden cultivation is almost never the sole method of farming employed by upland peoples. Thus, in western and central Borneo, swidden cultivation is regularly combined with a variety of intermediate systems known in Sarawak as padi paya or "swamp-rice" cultivation. Padi paya agriculture combines elements of both swiddening and irrigated farming (cf. Pringle 1970:26-27). ${ }^{12}$ Thus cultivation begins in the same way as dry-rice farming with cutting, drying and burning, but farms are typically cleared from naturally fooded plots and as in irrigated systems, planting is typically done in seedbeds with seedlings usually transplanted into prepared fields.

In this connection, Sellato (1989) offers an alternative interpretation of the role of foragers in the Austronesian settlement of Borneo. He suggest that initially pre-Austronesian groups occupied the coastline and areas of inland and riverine rainforest before the first Austronesians arrived bringing with them a developed agricultural economy. While these newcomers almost certainly brought rice, Sellato argues that without metal tools, they were unlikely to have been able to extend rice agriculture into the interior rainforests of the island with any degree of effectiveness. ${ }^{13}$ Indeed, Sellato argues that the extensive opening of the interior of Borneo to swidden rice-cultivation came about only with the massive 
proto-historic migrations of groups like the Kayan, Iban and Ngaju Dayaks, all of whom expanded largely through areas previously occupied by only scattered populations of forest foragers. For the Iban, these migrations began in the mid-16th century and involved the settlement of areas inhabited chiefly by Bukitan and Ukit foragers and, in the lower river valleys and estuarine lowlands, by small communities of sago-cultivators (cf. Sandin 1967). Sellato thinks it likely that the early Austronesians were chiefly foragers rather than cultivators. In this, he appears to slip into the same dichotomizing argument he criticizes in others. More likely, they practised both cultivation and foraging. Some groups appear to have remained coast-bound, practising a mixed economy of forest foraging, fishing and horticulture - cultivating sago, fruit trees and tuber crops, and possibly, on a small-scale, swamp-rice. A few, living in the interior headwaters, subsisted as full-time foragers. Only later did swidden agriculturalists spread inland, through the interior of Borneo, bringing with them a permanent system of inland forest cultivation.

Finally, foraging groups, over much of central, southern and western Borneo, have historically maintained some degree of contact with one another (Sellato 1989:153ff.). ${ }^{14}$ In addition, they have also maintained long-term trading ties with surrounding longhouse communities. For centuries, probably millennia, trade has been a major feature of the economy of the Penan and other Borneo foragers. In a regional perspective, these groups have long occupied a specific niche in the interior economy, acting as the major source of forest products traded to riverine longhouses and so to the coast (Brosius 1990:6). Historically, this trade shaped important features of longhouse society in many parts of Borneo, including social ranking and external relations with coastal sultanates. But, while trade has played a significant role in the lives of the Penan and their neighbours, it does not, in itself, "explain" the existence of forest foragers in Borneo.

Traditionally, [the] Penan depended on longhouse peoples, particularly aristocrats, to act as mediators with the outside world and to serve as the conduit by which both information and material goods reached them. The traditional type of relationship existing between Penan and longhouse aristocrats was multi-dimensional in that longhouse peoples provided not just trade goods ... but other types of "services" as well (1990:6).

Trade, important as it was, did not, however, involve subsistence inter-dependence (1990:6). Thus, foodstuffs were not, for either party, an item of trade. Finally, traditional trading ties were formed primarily with stratified societies. This is because, Sellato (1989:224) argues, egalitarian peoples like the Iban historically engaged in forest collection-for-trade themselves. As a result, when they encountered competing foragers, they tended either to absorb or 
displace them rather than engage them as trading partners. With stratified groups, trade was, and remains, largely monopolized by upper stratum families, whose economic position it enhances, while stratification itself prevents the easy assimilation of outsiders, thereby allowing trading relations to be maintained on a long-term basis without foragers losing their separate identity (cf. Sellato 1989: 224). Today, these traditional trading ties are breaking down as forests disappear and roads, timber camps and permanent market settlements increasingly penetrate the territories of former nomads.

In conclusion, the evidence from Borneo suggests that Austronesian settlement involved, initially, neolithic populations possessing a diverse economy combining secondary foraging, hunting and fishing with varied forms of horticulture, including the cultivation of sago, fruit and tuber crops, as well as rice, with individual groups radiating, as they settled the island, into a multitude of local economic niches. Even rice cultivation appears to have undergone diversification in Borneo. Thus, while some groups appear to have adapted to the Bornean rainforest as relatively self-contained foragers; others took up a mixed economy combining forest-collection-for-trade with farming; while a fully-developed system of swidden rice-cultivation, rather than being a "primitive" adaptation that early on in its settlement history opened the interior of the island to both horticulturalists and forest foragers alike, may have developed as a relatively late florescence. ${ }^{15}$

\section{Conclusion}

Foraging economies existed in Island Southeast Asia, including Borneo and the Philippines, long before the spread of Austronesian-speaking peoples. On this point, the archaeological record is clear. But, with the arrival of the Austronesians, the nature of these economies was almost certainly transformed. Foragers were enveloped with agriculturalists and others in networks of symbiotic exchange. One consequence of this envelopment may well have been an expansion of foraging itself, now by Austronesian-speaking peoples, into a variety of previously unexploited or little utilized ecosystems, including possibly the ever-wet rainforest. More likely, rainforest foraging was already practised, but was intensified by trade and made more effective as a result of contact with settled, technically advanced agricultural populations.

Another expansion was almost certainly into the coastal foreshores and sheltered offshore waters and reefs. Here, however, the development of an early foraging tradition is still largely conjectural. While maritime technologies clearly played a part in the spread of the Austronesians, whether boat-nomadic groups were involved or not is far less certain. More probably, as Bellwood suggests, maritime specializations developed out of the process of expansion itself. And as Urry argues, the geography of the Indo-Malaysian Archipelago itself would have been a powerful stimulus to such a development. What we do know is 
that, by the time of European penetration, maritime foragers were already widely dispersed throughout much of Island Southeast Asia, some of them, like the Sama-Bajau, phenomenally so. How long the ancestral traditions to these historical forms of boat nomadism may have been present is uncertain, although evidence for the Sama-Bajau suggests that scattered groups of sea nomads may have emerged by as much as 1000 years ago, perhaps earlier. Whatever the case, maritime boat people contributed in a major way to later Austronesian history, particularly to the early development of maritime trading states and to the networks of communication and long-distance commerce on which these states were founded.

\section{References}

Andaya, Leonard

1974 The structure of power in seventeenth century Johor. In Anthony Reid and Lance Castles (eds) Pre-colonial state systems in Southeast Asia: the Malay Peninsula, Sumatra, Bali-Lombok, South Celebes, pp.1-11. Kuala Lumpur: Monographs of the Malaysian Branch of the Royal Asiatic Society, No. 6.

1975 The kingdom of Johor, 1641-1728. Kuala Lumpur: Oxford University Press.

Anderson, G.

1890 The Selungs of the Mergui archipelago. London: Truber and Co.

Anderson, J.A.R. et al.

1982 Gunung Mulu National Park, Sarawak: a management and development plan. London: Royal Geographic Society.

Bailey, Robert C., Genevieve Head, et al.

1989 Hunting and gathering in tropic rain forest: is it possible? American Anthropologist 91:59-82.

Bellwood, Peter

1985 Prehistory of the Indo-Malaysian archipelago. Sydney: Academic Press.

1988 Archaeological research in South-Eastern Sabah. Kota Kinabalu: Sabah Museum Monograph, 2.

1989 Archaeological investigations at Bukit Tengkorak and Segurong, Southeastern Sabah. Bulletin of the Indo-Pacific Prehistory Association 9: 122-162.

1993 Cultural and biological differentiation in Peninsular Malaysia: the last 10,000 years. Asian Perspectives 32:37-60.

Bellwood, Peter and Peter Koon 
1989 'Lapita colonists leave boats unburned!' The question of Lapita links with Island Southeast Asia. Antiquity 63:613-622.

Benjamin, Geoffrey

1979 Indigenous religious systems of the Malay Peninsula. In A. Becker and A. Yengoyan (eds) The imagination of reality: essays in Southeast Asian coherence systems, pp.9-27. Norwood: Ablex Publishing.

1985 In the long term: three themes in Malayan cultural ecology. In Karl L. Hutterer, A. Terry Rambo and George Lovelace (eds) Cultural values and human ecology in Southeast Asia, pp.219-278. Michigan Papers on South and Southeast Asia, No. 27, Center for South and Southeast Asian Studies. Ann Arbor: University of Michigan.

1986 Between Isthmus and Islands: reflections on Malayan Palaeo-sociology. Department of Sociology, Working Paper No. 71. Singapore: National University of Singapore.

1990 Ethnohistorical perspectives on Kelantan's prehistory. In Nik Hassan Shuhaimi (ed.) Kelantan zaman awal: kajian arkeologi dan sejarah di Malaysia. Kota Bharu: Muzium Negara Kelantan.

Blust, Robert

1976 Austronesian culture history: some linguistic inferences and their relations to the archaeological record. World Archaeology 8:19-43.

1984-5 The Austronesian homeland: a linguistic perspective. Asian Perspectives 26(1):45-69.

1989 Comments. Current Anthropology 30:53-54.

Brosius, J. Peter

1986 River, forest and mountain: the Penan Gang landscape. Sarawak Museum Journal 36:173-184.

1988 A separate reality: comments on Hoffman's The Punan. Borneo Research Bulletin 20:81-106.

1990 Penan hunter-gatherers of Sarawak, East Malaysia. AnthroQuest 42:1-7.

1991 Foraging in tropical rain forests: the case of the Penan of Sarawak, East Malaysia. Human Ecology 19:123-150.

Carrapiett, W.J.S.

1909 The salons. Rangoon, Burma: Ethnographic Survey of India No. 2.

Chang, Te-Tzu

1984 The ethnobotany of rice in Island Southeast Asia. Asian Perspectives 26 (1):69-76. 
Christie, Jan

1988 Ironworking in Sarawak. In J.W. Christie and V.T. King (eds) Metalworking in Borneo, pp.1-27. Occasional Paper, 15. Centre for South-East Asian Studies, The University of Hull.

Dunn, F.L.

1975 Rain-forest collectors and traders: a study of resource utilization in modern and ancient Malaya. Monographs of the Malaysian Branch, Royal Asiatic Society, No. 5.

Dunn, F.L. and D.F. Dunn

1984 Maritime adaptations and exploitation of marine resources in Sundaic Southeast Asian Prehistory. In Pieter van de Velde (ed.) Prehistoric Indonesia: a reader, pp.244-271. Dordrecht: Foris Publications.

Ekman, Sven Petrus

1953 Zoogeography of the sea. London: Sidgwick and Jackson.

Endicott, Kirk M.

1984 The economy of the Batek of Malaysia: annual and historical perspectives. Research in Economic Anthropology 6:29-52.

Endicott, Kirk and Peter Bellwood

1991 The possibility of independent foraging in the rain forest of Peninsular Malaysia. Human Ecology 19:151-186.

Engelhardt, Richard

1987 Forest-gatherers and strand-loopers: econiche specialization in Thailand. Unpublished paper, The Siam Society Symposium, Enduring Autochthonous Adaptations.

Fox, James

1977 Notes on the southern voyages and settlements of the Sama-Bajau. Bijdragen tot de Taal-, Land-en Volkenkunde 133:459-465.

Frake, Charles O.

1980 The genesis of kinds of people in the Sulu Archipelago. In Language and cultural descriptions: essays by Charles O. Frake, pp.311-332. Stanford: Stanford University Press.

Geoghegan, William H.

1984 Sama. In Richard V. Weekes (ed.) Muslim peoples: a world ethnographic survey, Vol. 2, pp.654-659. London: Aldwych Press.

Harrisson, Tom 
1949 Notes on some nomadic Punans. Sarawak Museum Journal 5:130-146.

Headland, Thomas N.

1987 The wild yam question: how well could independent hunter-gatherers live in a tropical rain forest ecosystem? Human Ecology 15:463-491.

Headland, Thomas and Lawrence Reid

1989 Hunter-gatherers and their neighbors from prehistory to the present. Current Anthropology 30:43-51.

Hoffman, Carl

1984 Punan foragers in the trading networks of Southeast Asia. In C. Schrire (ed.) Past and present in hunter gatherer studies, pp.123-149. London: Academic Press.

1986 The Punan: hunters and gatherers of Borneo. Ann Arbor: UMI Research Press.

Hogan, David

1972 Men of the sea: coastal tribes of south Thailand's west coast. Journal of the Siam Society 60:205-235.

1989 Urak Lawoi': basic structures and a dictionary. Pacific Linguistics Series C No. 109, Canberra: Department of Linguistics, Research School of Pacific Studies, The Australian National University.

Hutterer, Karl

1976 An evolutionary approach to Southeast Asian cultural sequence. Current Anthropology 17:221-241.

1983 The natural and cultural history of Southeast Asian agriculture: ecological and evolutionary considerations. Anthropos 78:169-212.

Hutterer, Karl (ed.)

1977 Economic exchange and social interaction in Southeast Asia. Ann Arbor: University of Michigan Center for South and Southeast Asian Studies.

Ivanoff, Jacques

1985 L'epopée de Gaman: conséquences des rapports entre Moken/Malais et Moken/Birmans. Asie du Sud-Est et Monde Insulindien 16:173-194.

1987 Le concept de société “àmaison" confronté aux contradictions des cultures moken et moklen. In C. Macdonald (ed.) De la hutte au palais: sociétés "àmaison" en Asie du sud-est insulaire, pp.109-131. Paris: Editions du Centre National de la Recherche Scientifique.

Kedit, Peter M. 
1982 An ecological survey of the Penan. Sarawak Museum Journal 30:225279.

Kiefer, Thomas

1972 The Tausug polity and the sultanate of Sulu: a segmentary state in the southern Philippines. Sulu Studies 1:19-64.

Langub, Jayl

1988 The Penan strategy. In Judy Sloan Denslow and Christine Padoch (eds) People of the tropical rain forest. Berkeley: University of California Press.

1989 Some aspects of life of the Penan. Sarawak Museum Journal 40(3):169184.

Lebar, Frank et al.

1964 Mowken. Ethnic groups of mainland Southeast Asia, pp.263-266. New Haven: Human Relations Area Files Press.

Lewin, Roger

1988 New views emerge on hunters and gatherers. Science 240:1146-1148.

Logan, J.R.

1847 The Orang Sletar of the rivers and creeks of the old strait and estuary of the Johore. Journal of the Indian Archipelago and Eastern Asia 1:295298.

Macdonald, C. (ed.)

1987 De la hutte au palais: sociétés "àmaison" en Asie du sud-est insulaire. Paris: Editions du Centre National de la Recherche Scientifique.

Needham, Rodney

1972 Penan. In Frank LeBar (ed.) Ethnic groups of insular Southeast Asia, Vol. 1, pp.176-180. New Haven: Human Relations Area Files Press.

Nicholaisen, Johannes

1976a The Penan of Sarawak: further notes on the neo-evolutionary concept of hunters. Folk 18:205-236.

1976b The Penan of the seventh division of Sarawak: past, present and future. Sarawak Museum Journal 24:35-61.

Nimmo, H. Arlo

1972 The sea people of Sulu. San Francisco: Chandler.

Pallesen, A.K.

1985 Culture contact and language convergence. Manila: Linguistic Society of the Philippines. 
Sea Nomads and Rainforest Hunter-Gatherers: Foraging Adaptations in the Indo-Malaysian Archipelago

Pawley, Andrew and Roger Green

1973 Dating the dispersal of the Oceanic languages. Oceanic Linguistics 12:167.

Peacock, B.A.V.

1979 The later prehistory of the Malay Peninsula. In R.B. Smith and W. Watson (eds) Early South-East Asia: essays in archaeology, history and historical geography, pp.199-214. Oxford: Oxford University Press.

Pelras, Christian

1972 Notes sur quelques populations aquatiques de l'Archipel nusantarien. Archipel 3:133-168.

Peterson, J.T.

1978 Hunter-gatherer/farmer exchange. American Anthropologist 80:335-351.

Peterson, J.P. and W. Peterson

1977 Implications of contemporary and prehistoric exchange systems. In J. Allen et al. (eds) Sunda and Sahul. London: Academic Press.

Pringle, Robert

1970 Rajahs and rebels: the Iban of Sarawak under Brooke rule, 1841-1941. New York: Macmillan.

Reid, Anthony

1983 The rise of Makassar. Review of Indonesian and Malaysian Affairs 17:117160.

Reid, Lawrence

1987 The early switch hypothesis: linguistic evidence for contact between Negritos and Austronesians. Man and Culture in Oceania 3:41-59.

Rousseau, Jerome

1990 Central Borneo: ethic identity and social life in a stratified society. Oxford: Clarendon Press.

Saleeby, Najeeb

1908 The history of Sulu. Manila: Philippine Bureau of Science, Division of Ethnography Publications, Vol. 4, Part 2.

Sandbukt, Oyvind

1984 The sea nomads of Southeast Asia: new perspectives on ancient traditions. Annual Newsletter of the Scandinavian Institute of Asian Studies 17:3-13.

Sandin, Benedict

1967 The sea Dayaks of Borneo before white Rajah rule. London: Macmillan. 
Sather, Clifford

1971 Sulu's political jurisdiction over the Bajau Laut. Borneo Research Bulletin 3:58-62.

1975a Bajau Laut. In Frank LeBar (ed.) Ethnic groups of insular Southeast Asia, Vol. 2, pp.9-12. New Haven: Human Relations Area Files Press.

1975b Seven fathoms: a Bajau Laut narrative tale from the Semporna district of Sabah. Brunei Museum Journal 3(3):30-40.

1976 Kinship and contiguity: variation in social alignments among the Semporna Bajau Laut. In George Appell (ed.) The societies of Borneo, pp.4065. Washington, D.C: Special Publication of the American Anthropological Association, no. 6.

1978 The Bajau Laut. In Victor King (ed.) Essays on Borneo societies, pp.172192. Hull Monographs on Southeast Asia, 7. London: Oxford University Press.

1984 Sea and shore people: ethnicity and ethnic interaction in southeastern Sabah. Contributions to Southeast Asian Ethnography 3:3-27.

1985 Boat crews and fishing fleets: the social organization of maritime labour among the Bajau Laut of southeastern Sabah. Contributions to Southeast Asian Ethnography 4:165-214.

1990 Trees and tree tenure in Paku Iban society: the management of secondary forest resources in a long-established Iban community. Borneo Review 1 (1):16-40.

1993a Bajau. In David Levinson (ed.) Encyclopedia of world cultures, Vol. 5. New Haven: Human Relations Area Files Press.

1993b Samal. In David Levinson (ed.) Encyclopedia of world cultures, Vol. 5. New Haven: Human Relations Area Files Press.

Schrire, Carmel (ed.)

1984 Past and present in hunter-gatherer studies. London: Academic Press.

Seitz, S.

1981 Die Penan in Sarawak und Brunei: Ihre kulturhistorische Einordnung und derzeitige Situation. Paideuma 27:275-311.

Sellato, Bernard

1988 The nomads of Borneo: Hoffman and "devolution". Borneo Research Bulletin 20:106-120.

1989 Nomades et sédentarisation àBornéo. Paris: Éditions de l'École des hautes études en sciences sociales. 
Solheim, Wilhelm II

1975 Reflections on the new data of Southeast Asia prehistory: Austronesian origin and consequence. Asian Perspectives 18(2):146-160.

1984 The Nusantao hypothesis: the origin and spread of Austronesian speakers. Asian Perspectives 26(1):77-88.

Sopher, David

1965 The sea nomads: a study of the maritime boat people of Southeast Asia. Memoirs, No. 5. Singapore: National Museum.

Talla, Yahya

1979 The Kelabit of the Kelabit Highlands, Sarawak. Provisional Research Report, No. 9. Penang: School of Comparative Social Sciences, Universiti Sains Malaysia.

Urry, James

1981 A view from the west: inland, lowland and islands in Indonesian Prehistory. Unpublished paper presented at the 51st ANZAAS Congress, Brisbane.

Warren, Carol

1983 Ideology, identity and change: the experience of the Bajau Laut of East Malaysia, 1969-1975. South East Asia Monograph Series No. 14. Townsville: James Cook University.

Warren, James F.

1978 Who were the Balangingi Samal? Slave raiding and ethnogenesis in nineteenth-century Sulu. Journal of Asian Studies 37:477-490.

1979 The Sulu Zone: commerce and the evolution of a multi-ethnic polity, 1768-1898. Archipel 18:133-168.

1981 The Sulu Zone, 1768-1989. Singapore: Singapore University Press.

Wee, Vivienne

1985 Melayu: hierarchies of being in Riau. PhD dissertation, Canberra: The Australian National University.

White, Walter

1922 Sea Gypsies of Malaya. London: Seeley, Service.

Wolters, O.W.

1967 Early Indonesian commerce: a study of the origins of Srivijaya. Ithaca: Cornell University Press. 


\section{Studying Srivijaya. Journal of the Malaysian Branch of the Royal Asiatic} Society 52(2):1-32.

\section{Notes}

1 The latter Benjamin sees as antecedent to an emergent "Malay" tradition (1985: 226).

2 It also drew them eastward as well, of course, into Oceania.

3 The Moken and Orang Laut (including the Urak Lawoi) have sometimes been treated as if they constitute a single ethnolinguistic group (e.g. Lebar 1964). This, however, is not the case. Hogan (1989:2-4) discusses the linguistic relationship between the two groups. The Orang Laut are Malay-speakers and the cognate ratio between Moken-Moklen and Malay is only 44.51 to 45.60 per cent (Hogan 1989:3). The cognate ratio with Sama-Bajau is probably even lower, and it is significant therefore that these three sea nomadic groups, while all Austronesian-speaking, are only very remotely related to one another. Benjamin (pers.comm.) has suggested that the Aslian languages of the Malay Peninsula show evidence of contact with an earlier Austronesian language, prior to Malay, and has plausibly hypothesized that Moken may represent a continuing form of this language, surviving today as a northern outlier. More recently, Benjamin (1990) has suggested that the Moken themselves may have originally been Austroasiatic-speakers, who, living in a coastal setting, underwent an early language shift to Austronesian.

4 In the Semporna District of southeastern Sabah, Malaysia, in 1964-65, and more briefly, 1974 and 1979. Sama is the principal autonym used by most members of this group to refer to themselves; Bajau, Bajao, etc. is the chief exonym (see Sather 1993a and 1993b for a discussion).

${ }^{5}$ Early sources relating to the history of Sulu suggest an original dual governance, with complementary land and sea authorities. Thus the Balangingi and other Sama groups provided the naval forces of the sultanate. Later Tausug historiography has tended to obscure the importance of Sama mariners in the formation of the state, but there is evidence to suggest that they played a critical role, much like that of the Orang Laut in the rise of the first Malay states discussed presently.

6 Pallesen (1985:245) suggests, however, that Sama-Bajau is probably an Indonesian rather than a Philippine-related language family. He also suggests that it may have originated as a maritime creole.

7 Although overall population figures are not available, throughout the period 1964-74, the Sama Dilaut constituted slightly more than 5 per cent of the total Sama-speaking population of the Semporna District. 8 Dried fish, supplied by Orang Laut fishermen, was also a significant item of export trade in the early Malay states that developed in the Straits of Malacca (cf. Pallesen 1985:249).

9 As compared to some $150 \mathrm{~kg}$ for cultivated sago in Sarawak (Sellato 1989:159).

10 The swiddening cycle is, of course, of longer duration and involves the temporary destruction and burning of the forest cover. It may be worth noting that among the long-established Saribas Iban, upland swiddeners who regard themselves as quintessential rice-cultivators, a root-stock metaphor ( $\left.p u g u^{\prime}\right)$ is commonly used in prayers and invocation to describe a family's total store of rice seed and its collective powers of increase.

11 Brosius (1990:3) glosses molong as "to preserve or foster". The concept also applies to fruit trees. In Borneo similar systems of marking, applying to trees and other valued forest resources, are also employed by longhouse cultivators, including the Iban (see Sather 1990).

12 To highlight its intermediate status, Pringle (1970:27), writing specifically of the Iban, suggests that we might add to the familiar "wet" and "dry", the terms "damp rice". It is significant to note that paya cultivation is practised in the original Kapuas homeland of the Iban and was introduced with the first Iban migrations to the Batang Lupar and Saribas river systems in Sarawak. Thus, in Sarawak, padi paya cultivation would seem to have an antiquity equal to that of swiddening among the Iban. Despite the general association of the Iban with swidden cultivation, among some regional groups, e.g. the Balau Iban, padi paya culture forms the dominant system of rice cultivation.

13 Hutterer (1983) makes a similar argument for tropical rainforest cultivation generally. Thus, he argues that in such environments "major environmental modifications are far more difficult to achieve and require a relatively highly developed technology ... [including] metal tools" (1983:180, 186). This difficulty may partially account for the highly developed state of indigenous iron metallurgy in Borneo, including the traditional smelting of iron ore by tribal groups such as the Kayan (Christie 1988).

14 The rainforests of northern Borneo have never, in historical times, been occupied by populations of hunter-gatherers. Thus, in Sabah there are no indigenous populations comparable to Sarawak's Penan, 
Sea Nomads and Rainforest Hunter-Gatherers: Foraging Adaptations in the Indo-Malaysian Archipelago

Bukitan, Sihan, Ukit and others. However, cave sites in eastern Sabah were occupied by prehistoric foragers beginning by at least 18,000 BP (Bellwood 1988). What became of the descendants of these early hunter-gatherers, or how they might be related to contemporary foragers in other parts of Borneo, remains an unresolved question.

15 Botanically dryland varieties of rice appear to be a more recent evolution, pointing, in general, to the priority of wetland rice culture (cf. Chang 1984:71). 